\title{
Kampus sebagai miniatur keindonesiaan
}

\author{
Asep Wawan Jatnika ${ }^{a, 1^{*}}$, Epin Saepudin ${ }^{b, 2}$, Chairil Nur Siregar ${ }^{c, 3}$ \\ a, b, c Institut Teknologi Bandung \\ ${ }^{1}$ aswan_jatnika@yahoo.com ${ }^{2}$ epin.saepudin@itb.ac.id ${ }^{3}$ ril_gar@yahoo.com \\ * korespondensi penulis
}

\begin{abstract}
ABSTRAK
Keberhasilan "identitas" sebagai komoditas dalam kontestasi politik tanah air terjadi karena rendahnya pemahaman, penghargaan, dan pengakuan akan keberagaman. Implikasi dari rendahnya kompetensi dalam menyikapi keberagaman bangsa Indonesia berpangkal pada cara pandang terhadap perbedaan yang ada dalam masyarakat. Gejala rendahnya penghargaan akan keberbedaan belakangan ini sudah mulai memasuki dunia kampus dan ditengarai menjadi cikal bakal tumbuh kembangnya paham radikal di perguruan tinggi. Terlepas dari berbagai fenomena dan hasil penelitian yang menunjukkan bahwa radikalisme tumbuh subur di perguruan tinggi, tulisan ini mencoba memberikan perspektif lain dalam melihat kampus dengan cara pandang yang lebih positif. Lebih spesifik, bahasan akan difokuskan pada posisi strategis kampus sebagai miniatur keindonesiaan dan sebagai wahana pembudayaan nilai-nilai kebangsaan. Selain itu, akan diulas pula mengenai cara pandang, pola sikap, dan pola tindak terhadap keberagaman budaya, etnisitas, adatistiadat, dan agama yang hadir berdampingan di lingkungan kampus.
\end{abstract}

Kata kunci: identitas, kebangsaan, keberagaman

\section{ABSTRACT}

The success of "identity" as a commodity in political contestation in Indonesia due miss understanding, appreciation, and recognition of diversity. The implication of low competence in responding to the diversity of the Indonesian nation stems from the perspective of differences in society. Symptoms of low appreciation for diversity lately have started to enter the campus world and are suspected to be the forerunner to the growth of radical understanding in higher education. Apart from various phenomena and research results that show that radicalism thrives in universities, this paper tries to provide another perspective in viewing the campus with a more positive perspective. More specifically, the discussion will focus on the strategic position of the campus as a miniature of Indonesians and as a vehicle for the culture of national values. Besides, it will also review the perspective, attitude patterns, and patterns of action towards the diversity of cultures, ethnicities, customs, and religions that exist side by side in the campus environment.

Keywords: identity, nations, diversity

Copyright (C) 2019 Universitas Ahmad Dahlan, All Right Reserved

\section{PENDAHULUAN}

Indonesia mempunyai corak masyarakat multikultur yang terdiri dari berbagai agama dan sistem kepercayaan, suku bangsa, bahasa daerah, serta adat-istiadat yang tersebar dari Sabang sampai Merauke (Sudrajat, 2014). Hal demikian merupakan suatu kekayaan yang tak ternilai, karena tidak semua negara mempunyai karakteristik demikian. Pluralitas masyarakat merupakan rahmat di satu sisi, namun kutukan pada sisi yang lain, karena bagi masyarakat majemuk, peluang konflik sangat mungkin terjadi (Handoyo, Astuti, Iswari, Alimi, \& Mustofa, 2015). Karena itu, keanekaragaman masyarakat bak pisau bermata ganda, yang jika tidak dirawat dengan baik akan menjadi sebuah petaka.

Asumsi di atas relevan dengan situasi dan kondisi Indonesia belakangan ini, dimana berbagai persoalan berlatar belakang SARA gencar mendera Indonesia. Anam (2019) menjelaskan bahwa kerusuhan dan kekerasan yang terjadi di Indonesia akhir-akhir ini menunjukkan dikelola-nya keragaman dengan baik. Di samping itu, fenomena ini menunjukkan minimnya kearifan dan kebijaksanaan dari sebagian masyarakat untuk menghormati perbedaan baik yang bersifat intern maupun ekstern.

Rasa solidaritas etnis merupakan dasar dari banyak konflik dalam sejarah umat manusia (Tilaar, 2007). Secara historis, hal ini dapat dilihat dari sejarah perjuangan bangsa, dimana keragaman budaya dijadikan sebagai alat pemecah belah yang dapat mengikis persatuan dan kesatuan bangsa. Karena itu, tidaklah heran pada masa itu lahir berbagai kelompok warganegara, seperti Bumi Putera, Timur Asing, dan kelompok Barat.

Carut-marutnya kehidupan kebangsaan Indonesia yang mengarah pada konflik horizontal, tidak terlepas dari kondisi sosial politik tanah air yang memanas pada saat pemilihan umum yang 
baru saja terjadi (Nisa, 2016). Nilai-nilai primordialisme masih menjadi isu favorit dan dianggap sesuatu yang menjanjikan serta menjadi barang yang laku diperdagangkaan dalam kampanye politik (Abdullah, 2010). Lebih berbahaya lagi, ketika agama dijadikan sebagai isu politik (Nugraha, 2018). Minimnya pemahaman akan perbedaan keyakinan dan agama ditengarai dapat memicu konflik yang lebih besar karena bertalian dengan dimensi emosional individu (Dewi, 2017).

Konflik-konflik yang dilatari oleh ketidakmampuan dalam memahami dan memaknai keberagaman, dewasa ini turut memberi dampak pada kehidupan sivitas akademika di berbagai perguruan tinggi dan ditengarai sebagai cikal-bakal lahirnya gerakan-gerakan radikal (Asrori, 2017). Sebagaimana dilansir BNPT bahwa terdapat setidaknya 7 kampus yang terpapar paham radikal (CNN Indonesia, 2018).

Hasil penelitian yang dilakukan Setara Institute yang mengungkap 10 perguruan tinggi negeri di Indonesia terpapar paham radikal (Suara.com, 2019). Suburnya radikalisme di perguruan tinggi disebabkan semakin tingginya wacana dan gerakan keagamaan yang bersifat eksklusif (Rahayu, 2018). Salah satu gejala yang muncul adalah adanya kecenderungan membenci individu atau kelompok yang berbeda pandangan dengan kelompoknya (Basri \& Dwiningrum, 2019).

Maraknya konflik berbau SARA (terutama agama) yang berpotensi memecah-belah bangsa, sebenarnya merupakan sesuatu yang aneh (Munir, 2017). Karena sejatinya Indonesia memiliki Pancasila sebagai "philosophische groundslag" nya (Asmaroini, 2017). Secara empirik, Pancasila lahir diilhami nilai-nilai agama dan kepercayaan yang ada di Indonesia, hal mana dapat kita lihat pada sila pertama "Ketuhanan yang Maha Esa". Jika setiap elemen bangsa mampu memahami, memaknai dan melaksanakan setiap ajaran agamanya, maka konflik atas dasar perbedaan agama dan keyakinan tidak semestinya terjadi, karena pada dasarnya setiap agama selalu menekankan pada kesamaan dan kesetaraan dalam konteks kemanusiaan.

Jika ditelisik lebih jauh, munculnya percikanpercikan konflik di Indonesia didasari adanya perbedaan pemahaman, bahkan boleh jadi kekeliruan dalam memahami dan memaknai arti pluralisme dalam konteks kehidupan bermasyarakat, berbangsa dan bernegara (Sumbulah, 2015). Penerimaan akan perbedaan bukan hanya berkutat pada kompetensi keterampilan, melainkan lebih banyak terkait dengan persepsi dan sikap sesuai dengan realitas kehidupan secara menyeluruh.
Sebenarnya, potensi konflik dalam kera-gaman agama lebih banyak terjadi pada wilayah konstruksi sosial, bukan pada wilayah perenial agama (Arifin, 2009). Ini yang kemudian menjadi persoalan, karena hasil konstruksi manusia terhadap agama tidaklah tunggal, namun beragam sesuai jalan pikir, kemampuan, serta sudut pandang penafsir. Kaitan dengan itu, maka yang menjadi titik kunci dalam menyelesaikan persoalan tersebut adalah persamaan paradigm berpikir setiap warga bangsa dalam memandang dan memaknai keberagaman (Sakirin, 2018).

Namun demikian, terlepas dari berbagai fenomena, hasil penelitian, dan argumentasi sebagaimana diungkap di atas, tulisan ini mencoba memberikan perspektif lain dalam melihat kampus dengan cara pandang yang lebih positif. Lebih spesifik, bahasan akan difokuskan pada posisi strategis kampus sebagai miniatur ke-Indonesiaan dan sebagai wahana pembudayaan nilai-nilai kebangsaan. Selain itu, diulas pula mengenai cara pandang mahasiswa akan pluralitas di perguruan tinggi.

\section{METODE}

Penelitian ini dilakukan menggunakan pendekatan kualitatif dengan metode fenomenologi. Lokasi penelitian terletak di Institut Teknologi Bandung dengan subjek penelitian terdiri dari dosen dan mahasiswa. Pengumpulan data dilakukan dengan wawancara, studi dokumentasi, dan observasi. Selain itu, untuk melihat persepsi mahasiswa akan pluralisme, digunakan angket sebagai instrumen pendukung. Data yang terkumpul kemudian dianalisis menggunakan tiga tahap analisis data, meliputi; reduksi data, penyajian data, dan penarikan kesimpulan.

\section{HASIL DAN PEMBAHASAN}

\section{Kampus sebagai miniatur keberagaman bangsa Indonesia}

Kampus sebagaimana kita ketahui tidak hanya mengakomodir mahasiswa yang berasal dari wilayah dimana kampus itu berada. Institut Teknologi Bandung merupakan salah satu kampus yang dihuni oleh puluhan ribu mahasiswa yang berasal dari berbagai daerah di Indonesia. Persebaran daerah asal mahasiswa menjadikan ITB layak dikatakan sebagai miniatur ke-Indonesiaan, karena dihuni oleh insan dengan berbagai latar belakang sosial budaya, agama, suku bangsa, dan adat-istiadat yang merepresentasikan keberagaman bangsa Indonesia. Untuk menjelaskan posisi kampus sebagai miniatur ke-Indonesiaan, maka perlu dikaji terlebih dahulu persepsi mahasiswa akan keberagaman. 
Sebagian besar mahasiswa memandang pluralisme sebagai suatu paham yang menghargai adanya perbedaan di tengah kesamaan yang ada. Hal tersebut terealisasi dalam kehidupan keseharian masyarakat, terutama dalam menghargai perbedaan agama dan saling menghormati satu dengan yang lainnya. Konsepsi bhinneka tunggal ika harus sejalan dengan paham multikulturalisme yang mengajarkan bahwa terdapat satu benang merah (persamaan) di tengah perbedaan. Pluralis-me harus dimaknai sebagai kesediaan untuk menerima keberagaman, menjunjung toleransi dan sikap saling menghormati dan menghargai perbedaan suku, ras, agama, golongan, adat-istiadat, bahkan status sosial dan pandangan hidup.

Konsepsi pluralisme tidak hanya berlaku sempit, dalam arti hanya berkutat pada pengakuan adanya keberagaman agama, suku bangsa, dan etnis dalam masyarakat. Lebih daripada itu, pluralisme termasuk di dalamnya pengakuan akan adanya keberagaman dalam berpikir dan bertindak. Karena itu, untuk mencapai pluralisme diperlukan kematangan dari kepribadian sese-orang dan/atau sekelompok orang.

Selanjutnya, untuk memperkuat hasil wawancara yang dilakukan, peneliti kemudian menyebarkan angket kepada 104 mahasiswa yang dipilih secara acak. Lima pernyataan yang diajukan antara lain: 1) mampu berteman tanpa memandang perbedaan etnis, agama, dan adat-istiadat; 2) keragaman agama, keyakinan, budaya, adat istiadat, dan nilai-nilai tradisional merupakan kekayaan bangsa Indonesia; 3) Bhinneka Tunggal Ika merupakan ciri karakteristik bangsa yang harus dijunjung tinggi; 4) pluralisme mengajarkan sikap menghormati dan menghargai perbedaan; dan 5) kekayaan budaya lokal yang dimiliki Indonesia akan mendorong ke arah kemajuan. Berikut merupakan data yang terhimpun.

Kesatu, sebanyak $94,9 \% \quad$ mahasiswa memandang bahwa jalinan pertemanan dilakukan tanpa memandang perbedaan etnis, agama, dan adat-istiadat. Kedua, sebanyak 83,7\% memandang keberagaman agama dan keyakinan, budaya, adat istiadat, dan nilai-nilai tradisional merupakan kekayaan bangsa Indonesia. Ketiga, sebanyak 84,7\% memandang Bhinneka Tunggal Ika merupakan ciri karakteristik bangsa yang harus dijunjung tinggi. Keempat, sebanyak 83,6\% memandang pluralisme mengajarkan mahasiswa untuk menghormati dan menghargai perbedaan. Kelima, sebanyak $71,2 \%$ mahasiswa menolak etnosentrisme yang mengunggulkan kebudayaan-nya sendiri, sebaliknya mereka memahami bahwa dengan kekayaan budaya lokal lah Indonesia akan menuju ke arah kemajuan.
Data di atas diperkuat dengan observasi yang dilakukan oleh peneliti terhadap kehidupan keseharian mahasiswa di kampus. Berdasarkan hasil pengamatan yang dilakukan, utamanya dari cara berinteraksi antarsesama, menunjukkan bahwa mahasiswa sudah mampu berbaur dengan sesama tanpa sekat perbedaan, baik perbedaan etnis, agama, maupun latar belakang sosial budaya

Berangkat dari data di atas, maka secara umum mahasiswa sudah mampu memaknai keberagaman sebagai sesuatu yang lumrah, tidak menjadi jurang pemisah untuk berinteraksi. Bahkan keberagaman etnis, suku bangsa, budaya, dan bahasa daerah pun tidak lantas menjadikan mahasiswa berpandangan sempit akan budaya dan etnisnya sendiri, melainkan kekayaan dan karakteristik kebudayaan lokal menjadikan Indonesia sebagai sebuah entitas semakin kaya.

Hal ini menjadi suatu harapan baru untuk menjawab bahwa kampus saat ini masih menjalankan fungsinya sebagai penjaga nilai-nilai kebangsaan. Pemahaman atas pentingnya toleran-si mesti menjadi keniscayaan dalam rangka membangun masa depan yang lebih baik. Hanya dengan cara itu, kehidupan ini akan lebih bermakna dan bermanfaat. Pemahaman akan keberagamaan yang lebih inklusif-pluralis, multikultural, humanis, dialogis-persuasif, kontekstual, substantif, dan aktif sosial perlu dibangun (Yaqin, 2005). Karena sejatinya tindakan itu berangkat dari cara pandang terhadap sesuatu, dalam hal ini persepsi mengenai keberagaman.

Pandangan tersebut memosisikan manusia sebagai pencipta realitas, terutama jika dilihat dari tafsir manusia atas fenomena yang tampak (Berger, 2013). Sejalan dengan itu, dalam proses sosial, manusia dipandang sebagai pencipta realitas sosial yang relatif bebas di dalam dunia sosialnya (Bungin, 2011). Ini menunjukkan bahwa manusia dapat melakukan apapun, termasuk dalam mengkonstruksi realitas yang dipandang-nya menjadi sebuah pengetahuan baik bagi dirinya ataupun bagi orang lain.

Multikulturalisme sebagai sebuah konsep berbangsa dan bernegara mensyaratkan masyarakat untuk bisa menerima dan memahami keberagaman sebagai realitas sosial yang terus berkembang, bertujuan mengakui keberadaan kaum minoritas, dan menjadi dasar kebijakan untuk mendamaikan konflik antara kelompok minoritas dengan mayoritas. Sebagaimana dikemukakan Nathan (2015) bahwa "we live in the world of three basic social facts, namely, (1) human diversity is inevitable, (2) we live in an ethical plural society and (3) we are interdependent beings". 
Hal ini pula yang jauh sebelumnya sudah dipersiapkan oleh para pendiri bangsa, yakni dengan membangun sebuah sistem nilai yang mampu mengakomodir semua kepentingan dan golongan, yakni Pancasila. Pancasila sebenarnya merupakan satu upaya para founding fathers untuk membangun dan menata Indonesia yang pluralistik menjadi multikulturalistik (Molan, 2015).

Pancasila harus dipahami sebagai sebuah sistem dan tata laku dalam kehidupan berbangsa dan bernegara. Pancasila tidaklah mengatur bah-wa segenap warga bangsa harus seragam dalam berbagai dimensinya, namun justru hiduplah bersama dalam keberagaman. Oleh karena itu, lahirlah semboyan Bhinneka Tunggal Ika yang mengandung makna "walaupun berbeda, tetapi tetap satu jua".

Namun demikian, konsepsi dan gagasan mengenai pluralisme, multikulturalisme, dan penghargaan akan keberbedaan tidak akan bermakna apa-apa jika hanya selesai di alam pikiran, dalam arti harus mewujud dalam tindakan. Pluralisme tidak semata-mata menunjuk pada kenyataan akan adanya kemajemukan, tetapi keterlibatan aktif terhadap kenyataan kemajemukan tersebut (Haryanto, 2012).

Dengan demikian tiap individu tidak hanya dituntut untuk mengakui keberadaan individu yang berbeda, tetapi terlibat aktif dalam usaha memahami perbedaan yang ada untuk kemudian menarik benang merah (persamaan) dari perbedaan yang ada guna tercapainya kerukunan hidup bersama. Pluralisme oleh karena itu jangan dipandang secara parsial dalam pengertian kosmopolitanisme, relativisme, ataupun sinkretisme. Pluralisme harus menjadi bangunan kerukunan itu sendiri, yakni kemauan aktif untuk menerima perbedaan dan membangun kerukunan dalam perbedaan tersebut.

Implementasi pluralisme di perguruan tinggi bahkan lebih kompleks dari hanya berkutat pada perbedaan latar belakang sosial-budaya, agama, suku bangsa, dan adat-istiadat. Di kampus pemahaman akan adanya keberbedaan, diterjemahkan dengan berbagai aktivitas akademik, yakni dengan membangun suatu kesepahaman dalam menyelesaikan masalah yang dihadapi tanpa menonjolkan perbedaan disiplin ilmu, sehingga tercipta suatu kolaborasi berbasis keilmuan yang lintas disiplin. Keberbedaan masing-masing disiplin ilmu tidak dipandang sebagai penghalang persatuan, melainkan justru saling melengkapi antar satu dan lainnya.

\section{Memperkokoh prinsip Bhinneka Tunggal Ika di perguruan tinggi}

Keberagaman sivitas akademika di perguruan tinggi, baik dari sisi agama, budaya, etnisitas, dan adat-istiadat, sejatinya dipersatukan oleh kesamaan almamater, kesamaan visi, kesamaan misi, dan pada akhirnya membangun satu nilai yang diakui dan diyakini bersama. Karena itu, sejatinya kampus harus mampu menjadi penjaga gawang nilai-nilai kebangsaan. Sekalipun kampus memiliki berbagai program studi dan jurusan, akan tetapi harus dipahami bahwa semua keilmuan yang dipelajari harus diberdayagunakan untuk mendukung kemajuan dan peradaban bangsa.

Tidak ada pendidikan tinggi di mana pun yang melawan nilai-nilai kebangsaannya. Karena itu, setiap individu yang ada di kampus (tanpa dilihat apa program studinya) harus memiliki satu cara pandang dan cara berpikir yang sama dalam melihat realitas kebangsaan Indonesia.

Maraknya fenomena memudarnya nilai-nilai kebangsaan, bahkan disinyalir pula terjadi di perguruan tinggi menandakan harus ada upaya terstruktur, sistematis, komprehensif, dan massif mengenai pembudayaan nilai-nilai kebangsaan. Pembudayaan nilai-nilai kebangsaan yang salah satunya berkait dengan pengakuan akan keberbedaan, menghendaki situasi kampus yang tidak segmentatif.

Kampus merupakan tempat yang menghendaki adanya keberbedaan dalam pandangan, dalam arti membuka ruang bagi siapa pun untuk memberikan analisisnya, tentu didasari dengan bangunan teori dan argumentasi yang rasional. Dalam konteks ini, kampus harus berposisi sebagai mimbar untuk tumbuh suburnya kebebasan berpikir.

Berkenaan dengan strategi pembudayaan nilai Bhinneka Tunggal Ika, diperlukan serangkaian aktivitas yang sengaja di setting untuk menumbuhkembangkan kemampuan saling menghormati dan menghargai keberagaman. Sebagaimana kita tahu bahwa pembelajaran sikap hanya dapat dilakukan melalui tiga hal; pembiasaan (habituasi), internalisasi nilai (melalui pendidikan), dan penguatan komitmen politik kewargaan. Perlu kita dalami pernyataan ini, bahwa "pikiran mempengaruhi kata-kata, kata-kata mempengaruhi tindakan, tindakan mempengaruhi kebiasaan, kebiasaan pada akhirnya menjadi karakter". Pembudayaan nilai kebhinekaan tunggal ika-an oleh karena itu perlu dilakukan secara terstruktur, sistematis, dan masif.

Kesatu, terstruktur mengandung makna upaya pembudayaan nilai kebangsaan harus dilakukan secara berjenjang, mulai dari tingkat satu hingga 
tingkat akhir. Kedua, sistematis yakni memiliki pola yang menunjukkan keterpaduan antar satu aktivitas/tindakan dengan tindakan yang lainnya. Dalam konteks ini, dosen pendidikan kewarganegaraan misalnya telah membekali pengetahuan dan pemahaman mahasiswa mengenai nilai-nilai kebangsaan yang harus dipahami dan dilaksanakan dalam kehidupan keseharian sebagai warga bangsa. Selanjutnya, dosen pada program studi yang lebih spesifik turut serta membuat relasi kebermaknaan Pancasila dalam pengembangan keilmuan. Keilmuan yang dipelajari harus dikembalikan pada dimensi aksiologis yang benar, yakni untuk meningkatkan mutu kemanusiaan. Ketiga, massif-nya pembudayaan nilai kebangsaan mengandung arti bahwa upaya tersebut harus benarbenar dilaksanakan secara utuh dan komprehensif, jangan sampai upaya sosialisasi, internalisasi, dan pembudayaan nilai-nilai kebangsaan menyisakan sekelumit pertanyaan yang belum terjawab. Sebaliknya, upaya tersebut harus mampu memberikan pencerahan bahwa nilai-nilai kebangsaan yang telah disepakati bersama dapat menjadi pencerah bagi bangsa.

Berdasarkan hasil penelitian yang dilakukan, pengokohan prinsip Bhinneka Tunggal Ika yang dilaksanakan di ITB setidaknya dibangun oleh dua pola. Kesatu, pembudayaan nilai Bhinneka Tunggal Ika melalui penguatan Mata Kuliah Wajib Umum (MKWU). Kedua, pembudayaan nilai Bhinneka Tunggal Ika melalui internalisasi nilai universitas.

\section{a. Pembudayaan Nilai bhinneka tunggal ika melalui penguatan mata kuliah wajib umum}

Eksistensi MKWU di perguruan tinggi berfungsi untuk memberikan fondasi nilai-nilai kebangsaan sebagai arah gerak dan orientasi pengembangan keilmuan dalam membangun peradaban bangsa. Mata kuliah Agama, Panca-sila, Kewarganegaraan, dan Bahasa Indonesia secara sinergis berupaya untuk menciptakan satu kesepahaman tentang konsepsi kehidupan berbangsa dan bernegara.

Posisi strategis mata kuliah wajib umum terutama berada pada wilayah penyiapan generasi penerus bangsa (mahasiswa) yang mampu melanjutkan estafet kepemimpinan nasional. Mahasiswa sebagai komponen utama penerus pembangunan perlu dibekali berbagai kompetensi. Bukan hanya kompetensi intelektual berupa kemampuan untuk mendayagunakan nalar dan pemikirannya, tetapi juga kompetensi moral yang ditunjukkan oleh perilaku-perilaku yang selaras dengan kaidah, norma, kepribadian dan jatidiri bangsa. Karena pintar saja tidak cukup, tetapi harus pula berperilaku dan berkarakter baik.
Sebenarnya, perguruan tinggi dewasa ini sudah sangat baik dalam pengembangan kompetensi intelektual, akan tetapi masih lemah dalam penguatan kapasitas moral, terutama pada dimensi perasaan moral (moral feeling) dan tindakan moral (moral action). Dimensi moral merujuk pada sikap dan perilaku yang ditampilkan oleh individu telah sejalan dengan tuntutan nilai, norma, dan moralitas publik (berlaku umum). Dimensi ini tidak hanya berkutat pada tataran konseptual-filosofis, melainkan lebih substantif menyasar pada cara-cara berperilaku dalam kehidupan keseharian.

Secara operasional, MKWU diarahkan untuk melakukan penetrasi nilai-nilai dasar bagi matamata kuliah lainnya yang relevan di Perguruan Tinggi. Program MKWU menopang dasar dan mendukung ketercapaian fungsi dan tujuan pendidikan nasional yakni mengembangkan kemampuan dan membentuk watak serta peradaban bangsa yang bermartabat dalam rangka mencerdaskan kehidupan bangsa, bertujuan untuk berkembangnya potensi peserta didik agar menjadi manusia yang beriman dan bertakwa kepada Tuhan Yang Maha Esa, berakhlak mulia, sehat, berilmu, cakap, kreatif, mandiri, dan menjadi warga negara yang demokratis serta bertanggung jawab (Pasal 3 Undang-Undang Republik Indonesia No. 20 Tahun 2003 Tentang Sistem Pendidikan Nasional, 2003). Kaitan dengan itu, kedudukan MKWU di Perguruan Tinggi berfungsi membekali, membina, dan mengarahkan mahasiswa pada keyakinan, kepribadian, moral, nilai-nilai Agama, nilai-nilai kebangsaan, dan memajukan kebudayaan nasional

MKWU berorientasi pada pengembangan dan pembentukan karakter mahasiswa yang tidak hanya cerdas secara intelektual namun cerdas secara moral, mentalitas, dan berkepribadian yang baik sehingga menjadi manusia Indonesia seutuhnya. Keberadaannya turut serta dalam menanamkan nilai-nilai dan semangat menerapkan nilai, serta memberikan wawasan yang luas. Oleh karenanya, ia diberikan kepada seluruh mahasiswa terlepas dari disiplin ilmunya.

Secara filosofis, keberadaan MKWU tidak terlepas dari pandangan hidup masyarakat, yang di dalamnya berisikan nilai-nilai luhur yang dapat dipertanggungjawabkan menurut pikiran mereka. Di Indonesia, landasan filosofis penyelenggaraan mata kuliah wajib umum adalah Pancasila. Kedudukan Pancasila sebagai landasan filosofis penyelenggaraan MKWU pada praksisnya diimplementasikan melalui serangkaian mata kuliah yang wajib dilaksanakan di Perguruan Tinggi.

UU tentang Pendidikan Tinggi secara tegas mengamanatkan bahwa "kurikulum pendidikan tinggi wajib memuat mata kuliah (a) Agama, (b) Pancasila, (c) Kewarganegaraan, dan (d) Bahasa 
Indonesia" (Pasal 32 Ayat (3) Undang-Undang Republik Indonesia Nomor 12 Tahun 2012 tentang Pendidikan Tinggi, 2012). Implikasinya, setiap satuan pendidikan tinggi, baik negeri maupun swasta, baik universitas maupun institute dan sekolah tinggi wajib mencantumkan dan melaksanakan empat mata kuliah ini dalam kurikulumnya, tanpa kecuali.

Kesatu, mata kuliah Agama merupakan pengejawantahan dari sila pertama Pancasila, yakni Ketuhanan Yang Maha Esa. Perguruan Tinggi wajib melaksanakan mata kuliah agama, baik agama Islam, Katolik, Protestan, Hindu, Budha, maupun Konghuchu. Mata kuliah agama diberikan kepada mahasiswa karena selain dibekali kemampuan dan keterampilan akademik, mahasiswa juga harus dibekali kesadaran bahwa hakikatnya mereka merupakan mahluk Tuhan YME dan proses pencarian ilmu pun sejatinya merupakan perintah Tuhan.

Kedua, mata kuliah Pancasila merupakan pengejawantahan daripada lima sila yang tertuang dalam Pancasila, terutama dalam dimensi filosofis. Para pendiri bangsa Indonesia telah menyatakan bahwa Indonesia dibangun oleh Pancasila sebagai Philosofische Grondslag nya Indonesia merdeka. Melalui mata kuliah ini, mahasiswa diingatkan kembali jati dirinya sebagai sebuah individu yang berhimpun menjadi sebuah bangsa.

Ketiga, mata kuliah Kewarganegaraan. Mata kuliah ini dilaksanakan sebagai lanjutan daripada mata kuliah Pancasila. Dimana, mata kuliah Pancasila lebih dominan muatan filosofis, sedangkan mata kuliah kewarganegaraan lebih kepada dimensi praksis Pancasila. Bagaimana mahasiswa sebagai warganegara Indonesia mengetahui, memahami, dan melaksanakan hak dan kewajibannya dalam berbangsa dan bernegara, bagaimana memahami konsepsi demokrasi, konsepsi hak asasi manusia, dan lain sebagainya.

Keempat, mata kuliah Bahasa Indonesia. Mata kuliah ini merupakan mata kuliah wajib bagi siapa pun yang menempuh Pendidikan di Indonesia. Bahasa Indonesia sebagai bahasa nasional perlu dipahami secara baik oleh segenap elemen bangsa, sehingga diantara mereka (mahasiswa yang berasal dari berbagai daerah) dapat berkomunikasi secara baik, lisan maupun tulisan.

Keempat mata kuliah di atas, dalam praksis-nya diterapkan dan menekankan pada multi-metode, metode integral (menyatukan pengetahuan dan kepribadian), metode pendidikan afektif, metode nalar dan amal, metode diskusi/dialog, dan kajian antar bidang disiplin ilmu (interdisipliner).

\section{b. Pembudayaan nilai Bhinneka Tunggal Ika melalui internalisasi nilai universitas}

Perguruan tinggi apapun yang ada di Indonesia harus diorientasikan untuk meningkatkan mutu peradaban dan kemanusiaan. Dalam konteks ini, setiap perguruan tinggi harus mengusung nilai-nilai yang sama sebagai wujud komitmen kebangsaan. Namun demikian, secara operasional penajaman dan pengejawantahan nilai-nilai kebangsaan yang dikembangkan masing-masing universitas berbeda antar satu dengan yang lain-nya, tetapi memiliki spirit dan substansi yang sama.

ITB sebagai salah satu perguruan tinggi ter-baik di Indonesia memiliki visi "menjadi perguruan tinggi yang unggul, bermartabat, mandiri, dan diakui dunia serta memandu perubahan yang mampu meningkatkan kesejahteraan bangsa Indonesia dan dunia. Untuk merealisasikan visi tersebut, misi yang diemban Institut Teknologi Bandung adalah menciptakan, berbagi dan menerapkan ilmu pengetahuan, teknologi, seni dan kemanusiaan serta menghasilkan sumber daya insani yang unggul untuk menjadikan Indonesia dan dunia lebih baik (Peraturan Pemerintah No. 65 Tahun 2013 Tentang Statuta Institut Teknologi Bandung, 2013).

Selain mempunyai visi dan misi di atas, Institut Teknologi Bandung juga terkenal dengan semboyannya "In Harmonia Progressio" yang bermakna keselarasan dalam kemajuan. Secara substantif semboyan ini merupakan semangat yang dibangun dan digelorakan oleh sivitas akademika Institut Teknologi Bandung, bahwa untuk mencapai kemajuan diperlukan keselarasan dalam berbagai dimensi kehidupan.

Semboyan yang di usung ITB sejalan dengan prinsip Bhinneka Tunggal Ika yang mengandung makna berbeda-beda tetapi satu tujuan. Jika ditelisik lebih dalam, Bhinneka Tunggal Ika sejatinya tidak hanya sekadar semboyan semata, melainkan mengandung makna yang sangat dalam, terutama dalam merepresentasikan realitas sekaligus harapan dan cita-cita bangsa Indonesia. Bhinneka tunggal ika merupakan cerminan keseimbangan antara dua unsur, yakni unsur perbedaan yang menjadi ciri keanekaan dengan unsur kesamaan yang menjadi ciri kesatuan (Mustansyir, 1995).

Keterpaduan dan keseimbangan menuntut adanya harmonisasi. Harmonisasi sebagai keseimbangan dan kesesuaian segi-segi dalam perasaan, alam pikiran dan perbuatan individu, sehingga tidak terjadi hal-hal ketegangan yang berlebihan yang setidaknya terdiri dari empat unsur dan makna (Goesniadhie, 2006). 
Kesatu, adanya hal-hal ketegangan yang berlebih. Kedua, menyelaraskan kedua rencana dengan menggunakan bagian masing-masing agar membentuk system. Ketiga, proses atau upaya untuk merealisasi keselarasan, kesesuaian, keserasian, kecocokan, dan keseimbangan. Keempat, kerja sama antara berbagai faktor yang sedemikian rupa, hingga faktor-faktor tersebut menghasilkan kesatuan yang luhur. Harmonisasi sebagai suatu proses hendak mengatasi sekat-sekat perbedaan yang ada demi satu pencapaian yang sama untuk diraih bersama.

Kaitan dengan itu, perguruan tinggi harus menjalankan politik Bhinneka Tunggal Ika melalui serangkaian strategi, kebijakan, dan aktivitasnya. Politik Bhinneka Tunggal Ika memiliki makna yang lebih luas, yakni membangun suatu kondisi yang memberikan peluang munculnya apresiasi terhadap budaya orang lain serta memandang perbedaan dan keberagaman merupakan kekayaan dan khazanah bangsa kita (Arif, 2013). Dengan pandangan tersebut, diharapkan sikap eksklusif yang selama ini bersemayam dalam otak kita dan sikap membenarkan pandangan sendiri (truth claim) dengan menyalahkan pandangan dan pilihan orang lain dapat diminimalisir atau bahkan dihilangkan.

ITB sebagai perguruan tinggi berwawasan kebangsaan, mengemban misi mencerdaskan, memajukan, dan menyejahterakan masyarakat Indonesia, serta memperjuangkan kemaslahatan umat manusia, dengan berpegang teguh pada asas universalitas, kebenaran, penalaran, kebebasan, kejujuran, keterbukaan, kebhinekaan, keadilan, serta kesetaraan. Selanjutnya, didorong oleh semakin meningkatnya tuntutan atas peran ilmu pengetahuan dan teknologi untuk percepatan pembangunan bangsa dan negara, Institut Teknologi Bandung terus berupaya untuk meningkatkan kontribusi bagi bangsa dengan melahirkan visi menuju entrepreneurial university dengan tiga ciri utama, yakni excellent in teaching, excellent in research, dan excellent in innovation.

\section{KESIMPULAN}

Kampus sebagai miniatur bangsa Indonesia memiliki sejumlah karakteristik, antara lain: a) dihuni berbagai insan dengan latar belakang sosial budaya, agama, dan adat-istiadat yang beragam; b) dapat mempersatukan keberagaman; c) mengakui dan menghargai adanya keberagaman dalam berpikir; dan d) kesepahaman dibangun dengan mengesampingkan perbedaan, menekankan sinergi, dan kolaborasi.

Pengokohan prinsip Bhinneka Tunggal Ika di perguruan tinggi menjalankan dua pola. Kesatu, melalui penguatan mata kuliah wajib umum (Agama, Pancasila, Kewarganegaraan, dan Baha-sa
Indonesia). Kedua, melalui internalisasi nilai universitas, "In Harmonia Progressio", yang sejalan dengan prinsip Bhinneka Tunggal Ika. Kedua pola tersebut dilaksanakan secara terstruktur, Sistema-tis, dan massif.

\section{UCAPAN TERIMA KASIH}

Peneliti mengucapkan terima kasih kepada Kementerian Riset, Teknologi, dan Pendidikan Tinggi yang sudah memberikan bantuan dana sehingga peneliti dapat menunaikan tugas penelitian. Ucapan terima kasih juga peneliti sampaikan kepada Institut Teknologi Bandung sebagai tempat dimana peneliti mengabdi, serta kepada para dosen dan mahasiswa yang telah bersedia menjadi narasumber dan membantu peneliti dalam proses pengumpulan data.

\section{DAFTAR PUSTAKA}

Abdullah, T. (2010). Refleksi selintas tentang primordialisme, pluralisme, dan demokrasi. Jurnal Masyarakat dan Budaya. https://doi.org/10.14203/JMB.V12I2.109

Anam, A. M. (2019). Konsep pendidikan pluralisme Abdurrahman Wahid (Gus Dur). Cendekia: Jurnal Kependidikan Dan Kemasyarakatan. https://doi.org/10.21154/cendekia.v17i1.14 42

Arif, D. B. (2013). Membingkai Ke-Bhinneka Tunggal Ika-an dalam Perspektif Mata Pelajaran Pendidikan Pancasila dan Kewarganegaraan. In Prosiding Seminar Nasional Revitalisasi Nilai-nilai Pancasila dan Implementasi Kurikulum PKn 2013 (hal. 108122).

Arifin, S. (2009). Kontruksi wacana pluralisme agama di indonesia. Humanity, V(1), 80-92.

Asrori, A. (2017). Radikalisme di Indonesia: Antara historisitas dan antropisitas. Kalam, 9(2), 253. https://doi.org/10.24042/klm.v9i2.331

Basri, B., \& Dwiningrum, N. R. (2019). Potensi radikalisme di perguruan tinggi (studi kasus di Politeknik Negeri Balikpapan). JSHP: Jurnal Sosial Humaniora dan Pendidikan, 3(1), 84-91. https://doi.org/10.32487/jshp.v3i1.546

Berger, D. (2013). Social movements and mass incarceration. Souls, 15(1-2), 3-18. https://doi.org/10.1080/10999949.2013.804 781

Bungin, B. (2011). Kontruksi sosial media massa. Jakarta: Prenada Media Group.

CNN Indonesia. (2018). BNPT: Kedokteran dan Eksakta di 7 PTN terpapar radikalisme. Diambil 23 Juli 2019, dari 
https://www.cnnindonesia.com/nasional/20 180525210629-12-301431/bnpt-kedokterandan-eksakta-di-7-ptn-terpapar-radikalisme

Dewi, R. K. (2017). Adaptasi budaya dalam pernikahan etnis Tionghoa-Jawa. Interaksi: Jurnal Ilmu Komunikasi, 6(2), 32-37. https://doi.org/10.14710/interaksi.6.2.32-37

Goesniadhie, K. (2006). Harmonisasi hukum dalam perspektif perundang-undangan: lex specialis suatu masalah. Surabaya: JP Books.

Handoyo, E., Astuti, T. M. P., Iswari, R., Alimi, Y., \& Mustofa, M. S. (2015). Studi Masyarakat Indonesia. Studi Masyarakat Indonesia.

Haryanto, J. T. (2012). Interaksi dan harmoni umat agama. Walisongo, 20(1), 211-234.

Molan, B. (2015). Multikulturalisme: Cerdas membangun hidup bersama yang stabil dan dinamis. Jakarta: Indeks.

Munir, S. (2017). Politik Pendidikan islam berbasis multikultural: konsep dan strategi pembelajaran agama islam dalam mewujudkan Islam rahmatan li al- ' à lam ì n. Dirosat.

https://doi.org/10.28944/dirosat.v2i2.105

Mustansyir, R. (1995). Bhinneka Tunggal Ika dalam perspektif filsafat analitik. Jurnal Filsafat "WISDOM," 22(Agustus), 46-58.

Nathan, G. (2015). A non-essentialist model of culture: Implications of identity, agency and structure within multinational/multicultural organizations. International Journal of Cross Cultural Management, 15(1), 101-124. https://doi.org/10.1177/1470595815572171

Nisa, J. (2016). Resolusi konflik dalam perspektif komunikasi. SALAM: Jurnal Sosial dan Budaya Syar-i, 2(1). https://doi.org/10.15408/sjsbs.v2i1.2240

Nugraha, M. T. (2018). Fundamentalisme pendidikan agama di jejaring sosial. Al-Tahrir: Jurnal Pemikiran Islam, 18(1), 41. https://doi.org/10.21154/altahrir.v18i1.1172

Peraturan Pemerintah No. 65 Tahun 2013 Tentang Statuta Institut Teknologi Bandung (2013).

Puji Asmaroini, A. (2017). Menjaga eksistensi Pancasila dan penerapannya bagi masyarakat di era globalisasi. Jurnal Pancasila dan Kewarganegaraan, 2(1), 59-72. https://doi.org/10.24269/v2.n1.2017.59-72

Rahayu, N. S. (2018). Hubungan mata kuliah pendidikan pancasila dengan persepsi mahasiswa terhadap radikalisme di era globalisasi. Jurnal Pendidikan Kewarganegaraan, 5(2), 97-106. https://doi.org/10.32493/jpkn.v5i2.y2018.p9 7-106

Sakirin, A. (2018). Mengenal Pluralisme Disintegratif Menuju Pluralisme Integratif Masyarakat Beda Agama di Kelurahan Karang, Kecamatan Slogohimo, Kabupaten Wonogiri. Ibriez: Jurnal Kependidikan Dasar Islam Berbasis Sains. https://doi.org/10.21154/IBRIEZ.V3I2.56

Suara.com. (2019). Survei Setara: UI, UGM, IPB, dan 7 PTN lainnya terpapar paham radikalisme. Diambil 25 Juli 2019, dari https://www.suara.com/news/2019/05/31/ 182859/survei-setara-ui-ugm-ipb-dan-7-ptnlainnya-terpapar-paham-radikalisme

Sudrajat, S. (2014). Revitalisasi pendidikan multikultural dalam pembelajaran. Jurnal Pembangunan Pendidikan: Fondasi dan Aplikasi, 2(1). https://doi.org/10.21831/jppfa.v2i1.2620

Sumbulah, U. (2015). Pluralisme dan kerukunan umat beragama. Analisa: Journal of Social and Religion.

Tilaar, H. (2007). Mengindonesia etnisitas dan identitas bangsa Indonesia: tinjauan dari perspektif ilmu pendidikan. Jakarta: Rineka Cipta.

Undang-Undang Republik Indonesia No. 20 Tahun 2003 Tentang Sistem Pendidikan Nasional (2003).

Undang-Undang Republik Indonesia Nomor 12 Tahun 2012 tentang Pendidikan Tinggi (2012).

Yaqin, M. A. (2005). Pendidikan multikultural: Crosscultural understanding untuk demokrasi dan keadilan. Yogyakarta: Pilar Media. 